\title{
Mediterranean standard for sustainable tourism (MESST) - general requirements, objectives and the philosophy of MESST
}

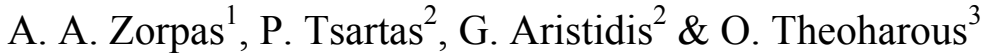 \\ ${ }^{1}$ Environmental Technology (Research Institute), Cyprus \\ ${ }^{2}$ University of the Aegean, Tourism Development, Greece \\ ${ }^{3}$ Cyprus Tourist Organizations, Cyprus
}

\begin{abstract}
Tourism is an activity that can have a truly major impact on sustainable development. EU recorded in excess of 440m visitor arrivals in 2005. Tourism, directly and indirectly, accounts for around $10 \%$ of European GDP and $20 \mathrm{~m}$ jobs. Europeans account for over half of all international travel, and visits by Europeans provide an important source of income for many developing countries. In 2005 the World Tourism Organization (UNWTO) and the United Nations Environment Programme (UNEP) identified an agenda of 12 aims for sustainable tourism. The EU Sustainable Development Strategy (SDS) has three key objectives: Economic prosperity, Social equity and cohesion and Environmental protection. Tourism businesses could function properly under the sustainability model and they have mentioned "environmental education programmes" and "establishment of co-operation and partnerships among local, regional and state stakeholders and authorities" as the most sustainable actions. The standard is and must be applicable to any organization that wishes to (a) Increase the environmental responsibility of tourism enterprises, (b) Increase the capacity of local administration on monitoring sustainable tourism, (c) Create a transactional network of shared planning and management policies for sustainable tourism, (d) Exchange best practices and knowledge in the field of sustainable tourism. This paper briefly describes the general requirements of MESST.
\end{abstract}

Keywords: sustainable development, tourism environment, Mediterranean standard, MESST, quality management, environment. 


\section{Introduction}

The Mediterranean region is the leading tourist destination worldwide. Tourism is mainly concentrated in the coastal areas that receive $30 \%$ of international tourist arrivals. The most widely used tourism development model used in the region is based on seaside summer holidays and the attainment of quantitative goals. Of the total $46,000 \mathrm{~km}$ of coastline, $25,000 \mathrm{~km}$ is urbanized and has already exceeded a critical limit. International tourist arrivals (excluding domestic arrivals) in 1999 totalled 219.6 million (4.7\% increase over 1998). Projections show that this figure could reach 350 million by $2020.84 \%$ of the tourists in the Mediterranean come from Europe, mostly from northern and western countries. Germany is the largest market followed by the United Kingdom, France and Italy. Spain, France, Italy, and Greece receive almost $80 \%$ of Mediterranean tourism. The Mediterranean receives $1 / 3$ of the income of international tourism. Tourism receipts in 1999 totalled US\$ 131.8 billion. Over the last three years, $2 / 3$ of the income returned to the hands of less than 10 tour operators from northern Europe. The environment and society of many Mediterranean destinations are under threat due to the inappropriate practice and development associated with mass tourism. With current development models based on quantity, the projected growth of tourism development in the region will continue to damage landscapes, cause soil erosion, put pressure on endangered species, further strain available water resources, increase waste and pollution discharges into the sea and lead to cultural disruption [1-4].

\subsection{Land and landscape: species-pollution and wastes - social and cultural impacts}

Construction related to tourism development (hotels, airports, roads, vacation homes) causes the greatest negative impact to the fragile coastal and marine ecosystems in the Mediterranean. Loss of biodiversity and landscape attractiveness already affects a number of tourist destinations throughout the region. The projected growth, if not properly managed, may continue to degrade these regions, as well as destroy what are now almost untouched areas, [1,2].

As a major cause of the loss of natural habitat, tourism has a very direct negative impact on biodiversity, directly affecting rare and endangered species. Over 500 plant species in the Mediterranean are threatened with extinction and are under intense pressure from tourism development in some overbuilt destinations. Freshwater concerns are reaching crisis levels in some Mediterranean countries as demand outstrips supply and desertification advances throughout the southern regions. During the summer months water supplies are exacerbated by tourist flows for use in hotels, swimming pools and golf courses. For example, an average Spanish city dweller uses approximately 250 litres of water per day, while the average tourist uses 440 litres. This number increases to 880 litres if the tourist uses accommodations with swimming pools and golf courses [1,2]. 
The Mediterranean Sea receives 10 billion tones of industrial and urban waste per year with or without any purification. The production of wastewater and solid waste in tourist areas often exceeds the carrying capacity of local infrastructures due the high seasonal demand. Pollution also negatively affects water quality in beach areas and drinking water supplies. The consequence to the human health could be serious. [1,2].

While tourism provides certain economic benefits to a region, it also causes disturbance to the local way of life as well as to social structures, and can adversely affect traditional practices that contribute to the conservation and sustainable use of biodiversity. It utilizes the physical environment for profits that are mainly directed out of the country, creating adverse impacts on livelihoods and lack of benefit sharing with the local people who will bear tourism related costs to both the human and natural environment. Additional resource use conflicts occur between tourism and local populations as they compete for limited resources of water, sanitation, energy and land uses. Finally economic leakages are not permitting the majority of tourism income to reach local populations, $[1,2]$.

\section{The application of sustainability principles}

There are a number of principles behind the concept of sustainable development that have a particular bearing on tourism and the approach we should take in Europe, $[1,2]$. Among them are the following:

- $\quad$ Taking a holistic and integrated approach: All the various impacts of tourism should be taken into account in its planning and development. Furthermore, tourism should be well balanced and integrated with a whole range of activities that affect society and the environment.

- $\quad$ Planning for the long term: Sustaining development is about taking care of the needs of future generations as well as ours own. Long term planning requires the ability to sustain actions over time.

- Achieving an appropriate pace and rhythm of development: The level, pace and shape of development should reflect and respect the character, resources and needs of host communities and destinations.

- Involving all stakeholders: A sustainable approach requires widespread and commitment participation in decision-making and practical implementation by all those implicated in the outcome.

- Using best available knowledge: Policies and actions should be informed by the latest and best knowledge available. Information on tourism trends and impacts, and skills and experience, should be shared across Europe.

- $\quad$ Minimizing and managing risk - the precautionary principle: Where there is uncertainty about outcomes, there should be full evaluation and preventative action should be taken to avoid damage to the environment or society.

- $\quad$ Reflecting impacts in costs-user and polluter pays: Prices should reflect the real costs to society of consumption and production activities. This 
has implications not simply fro pollution but for charging for the use of facilities that have significant management costs attached to them.

- $\quad$ Setting and respecting limits, where appropriate: The carrying capacity of individual sites and wider areas should be recognized, with a readiness and ability to limit, where and when appropriate, the amount of tourism development and volume of tourism flows.

- Undertaking continuous monitoring: Sustainability is all about understanding and being alert to them all the time, so that the necessary changes and improvements can be made.

The overall objective of MESST is the development of a standard on sustainable tourism for application in tourism destinations and enterprises in all the business cycle of tourism activity. The standard is and must be applicable to any organization that wishes to: (i) Increasing the environmental responsibility of tourism enterprises, (ii) Increasing the capacity of local administration on monitoring sustainable Tourism, (iii) Creating a transactional network of shared planning and management policies for sustainable tourism, (iv) Exchanging best practices and knowledge in the field of sustainable tourism

The whole philosophy of the new standard is to be simple and parallel with the other international standard like ISO 9001:2000, ISO 14001:2004, OHSAS 18001:2007, ISO 22000:2005. Tale 1 presents the philosophy of MESST in relation with the requirement of a quality management system.

\section{General requirements of MESST}

The organization shall establish, document, implement, maintain and continual improve the Mediterranean Standard for Sustainable Tourism Development in accordance's with the requirements of this Standard and determined how it will fulfil theses requirements. Top Management shall defined the organizations Sustainable Tourism Development Policy and ensure that, within the defined scope of its Sustainable Tourist Development Management System. The policy must: Includes Commitment for continual Improvement, Be documented, implemented and maintained, Include retention to the Local Culture, Include commitment for the monitoring of their waste (all the kinds) and prevention of the pollution, Include commitment for the application of all the legislations requirements, $\mathrm{Be}$ available to the public. Also the policy must include environmental, economic, and sustainability and management commitment policies according to the environmental \& cultural policies, economic policies, sustainability policies, management policies.

\subsection{Documentation requirements}

The organization shall establish, document, implement and maintain Sustainable Tourism Development Management System, which shall include:

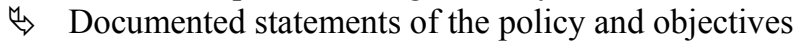

$\stackrel{4}{4}$ A manual

$\stackrel{4}{4}$ The scope of the s Sustainable Tourism Development Management System Documents required by the system shall be controlled as in ISO 9001:2000. 
Table 1: $\quad$ The requirements of MESST standard.

\begin{tabular}{|c|c|c|}
\hline $\begin{array}{l}\text { Paragraphs } \\
\text { of Draft } \\
\text { Version }\end{array}$ & Requirements of MESST (Draft Versions) & $\begin{array}{l}\text { ISO } 9001: 2000 \\
\text { requirements }\end{array}$ \\
\hline 0 & Introduction & \\
\hline 0.1 & $\begin{array}{l}\text { Tourism }- \text { a special relationship with } \\
\text { sustainable development }\end{array}$ & \\
\hline 0.2 & $\begin{array}{l}\text { Aims for the sustainability of European } \\
\text { tourism }\end{array}$ & \\
\hline 0.3 & Tourism in the Mediterranean & \\
\hline 0.4 & The application of sustainability principles & \\
\hline 0.5 & $\begin{array}{l}\text { Actions/ measures towards sustainable } \\
\text { tourism development }\end{array}$ & \\
\hline 0.6 & $\begin{array}{l}\text { A brief review of standards and certification } \\
\text { systems for sustainable tourism }\end{array}$ & \\
\hline 0.7 & $\begin{array}{l}\text { Comparative analysis on the destinations' } \\
\text { and business attitude towards sustainable } \\
\text { tourism in Malta, Cyprus, Rhodes and } \\
\text { Melandro }\end{array}$ & \\
\hline 1 & Scope & 1 \\
\hline 2 & Normative reference & 2 \\
\hline 3 & Terms and definitions & 3 \\
\hline 4 & $\begin{array}{l}\text { Mediterranean standard for sustainable } \\
\text { tourism (me.s.s.t) }\end{array}$ & 4 \\
\hline 4.1 & General requirements & $4.2 .1,4.2 .2$ \\
\hline 4.2 & Sustainable development policy & 4.3 \\
\hline 4.2 .1 & Environmental \& cultural policies & 4.3 \\
\hline 4.2 .2 & Economics policies & 4.3 \\
\hline 4.2 .3 & Sustainable policies & 4.3 \\
\hline 4.2 .4 & Management policies & 4.3 \\
\hline 4.3 & Document requirements & $\begin{array}{l}4.2,4.2 .1,4.2 .2 \\
4.2 .3,4.2 .4\end{array}$ \\
\hline 4.4 & Planning & $5,5.4 .1,5.4 .2$ \\
\hline 4.4 .1 & Legal and other requirements & $5.2,7.2 .1$ \\
\hline 4.4 .2 & $\begin{array}{l}\text { Sustainable tourism development objectives, } \\
\text { targets, pillars and programmes }\end{array}$ & $5.6,7$ \\
\hline 4.4.2.1 & $\begin{array}{l}\text { Objectives on a business level } 1 \text { - } \\
\text { environmental objectives }\end{array}$ & $\begin{array}{l}5.4 .1,5.4 .2 \\
8.5 .1\end{array}$ \\
\hline 4.4 .2 .2 & $\begin{array}{l}\text { Objectives on a business level } 2 \text { - } \\
\text { environmental objectives }\end{array}$ & $\begin{array}{l}5.4 .1,5.4 .2 \\
8.5 .1\end{array}$ \\
\hline 4.4 .2 .3 & $\begin{array}{l}\text { Objectives on a business level } 3 \text { - economic, } \\
\text { culture and social objectives }\end{array}$ & $\begin{array}{l}5.4 .1,5.4 .2 \\
8.5 .1\end{array}$ \\
\hline 4.4.2.3.1 & Economic objectives & 8.5 .1 \\
\hline 4.4 .2 .3 .2 & Cultural and Social Objectives & 8.5 .1 \\
\hline
\end{tabular}


Table 1: $\quad$ Continued.

\begin{tabular}{|c|c|c|}
\hline $\begin{array}{l}\text { Paragraphs } \\
\text { of Draft } \\
\text { Version }\end{array}$ & Requirements of MESST (Draft Versions) & $\begin{array}{l}\text { ISO } 9001: 2000 \\
\text { requirements }\end{array}$ \\
\hline 4.4 .3 & Objective on Destination Levels & 8.5 .1 \\
\hline 4.4 .3 .1 & Environmental objectives & $\begin{array}{l}\text { 5.4.1,5.4.2, } \\
8.5 .1\end{array}$ \\
\hline 4.4 .3 .2 & Cultural and Social Objectives & 8.5 .1 \\
\hline 4.4 .3 .3 & Monitoring objectives & 8.5 .1 \\
\hline 4.5 & Reducing Seasonality of Demand & $5.2,7.2 .1$ \\
\hline 4.6 & Addressing impact from tourism transport & $5.2,7.2 .1$ \\
\hline 4.7 & Improving the quality of tourism job & $5.2,7.2 .1$ \\
\hline 4.8 & $\begin{array}{l}\text { Maintain and enhancing community } \\
\text { prosperity and quality of life in the face of } \\
\text { change }\end{array}$ & $5.2,7.2 .1$ \\
\hline 4.9 & $\begin{array}{l}\text { Minimizing resource use and production } \\
\text { waste }\end{array}$ & $5.2,7.2 .1,7.2 .2$ \\
\hline 4.10 & $\begin{array}{l}\text { Conserving giving value to natural and } \\
\text { cultural heritage }\end{array}$ & $5.2,7.2 .1$ \\
\hline 4.11 & Making Holidays Available to All & $5.2,7.2 .1$ \\
\hline 4.12 & $\begin{array}{l}\text { Using Tourism as a Tool in global } \\
\text { sustainable development }\end{array}$ & $5.2,7.2 .1$ \\
\hline 5 & Technical requirements of MESST & \\
\hline 6 & Indicators & 8.5 .1 \\
\hline 7 & $\begin{array}{l}\text { Measuring the critical values of MESST } \\
\text { indicators }\end{array}$ & 8 \\
\hline 8 & Operation requirements of MESST & $\begin{array}{l}4,4.1,5.5,5.5 .1 \text {, } \\
5.5 .2,5.5 .3\end{array}$ \\
\hline 9 & Purchasing & 7.4 \\
\hline 10 & $\begin{array}{l}\text { Human Resource, awareness and training. } \\
\text { Education and Capacity Building }\end{array}$ & $\begin{array}{l}6.2,6.2 .1,6.2 .2, \\
6.3,6.4\end{array}$ \\
\hline 11 & Operation control & $\begin{array}{l}4,4.1,5.5,5.5 .1, \\
5.5 .2,5.5 .3,6.3, \\
6.4\end{array}$ \\
\hline 12 & Checking & 8.2 .2 \\
\hline 12.1 & Analysis Data - Customer satisfaction & 8.2 .1 \\
\hline 12.2 & Internal audit & 8.2 .2 \\
\hline 12.3 & Control of Non-Conforming product & 8.3 \\
\hline 12.4 & Corrective action / preventive actions & $8.5 .2,8.5 .3$ \\
\hline 12.5 & Continual improvement & 8.5 .1 \\
\hline 13 & Emergency preparedness and response & $8.5,6.4,6.3$ \\
\hline 14 & General management review & 5.6 \\
\hline \multirow[t]{3}{*}{15} & Reference & \\
\hline & Annex I. 12 aim for sustainable tourism & \\
\hline & Annex II. Indicators & \\
\hline
\end{tabular}




\subsection{Planning}

The organization shall establish, implement and maintain a procedure (s) in order to plan and organised their Sustainable Tourism Development Management System. The Organization shall establish, implement and maintain a procedure (s): (i) To identify and have access to the applicable legal requirements and other requirements to which the organization subscribes related to its activities (ii) To determinate how these requirements apply to its activity. Among the legal requirements must be given emphasis to the following subject: Environmental Legislations (Impact Assessments), Health and Safety Legislations (High risk accidents, Risk assessments), Food Hygiene Legislation, Human Resource Legislation. The organizations shall keep records of results of the periodic evaluations, $[1,2]$.

\subsection{Sustainable tourism development objectives, targets, pillars and programmes}

The organization shall establish, implement and maintain documented Objectives, Targets and Pillars at relevant functions and levels within the organization. The Objective, Targets and Pillars shall be measurable, where practice and consistent with the Policy, including the commitment to prevention of pollution, to compliance with the legal and other requirements to which the organization subscribes and to continual improvement. The common framework of the standard shall address the following Key Objectives areas: (i) Infrastructure and land-use planning and management, (ii) Leading environmental programs on a local or a regional basis, (iii) Establishment of multi- stakeholder participation and partnerships, (iv) Improving relationships with local communities.

\subsection{Technical requirements of MESST}

Sustainable tourism development guidelines and management practices should be applicable to all forms of tourism in all types of destinations, including mass tourism and the various niche tourism segments. Sustainability principles refer to the environmental, economic, and socio-cultural aspects of tourism development, and a suitable balance must be established between these three dimensions to guarantee its long-term sustainability. On this basis UNEP and UNWTO developed the so-called 12 aims for sustainable tourism development, which are briefly the following.

$\checkmark \quad$ Economic Viability: To ensure the viability and competitiveness of tourism destinations and enterprises, so that they are able to continue to prosper and deliver benefits in the long term.

$\checkmark \quad$ Local Prosperity: To maximize the contribution of tourism to the economic prosperity of the host destination, including the proportion of visitor spending that is retained locally. 
$\checkmark \quad$ Employment Quality: To strengthen the number and quality of local jobs created and supported by tourism, including the level of pay, conditions of service and availability to all without discrimination by gender, race, disability or in other ways.

$\checkmark \quad$ Social Equity: To seek a widespread and fair distribution of economic and social benefits from tourism throughout the recipient community, including improving opportunities, income and services available to the poor.

$\checkmark \quad$ Visitor Fulfilment: To provide a safe, satisfying and fulfilling experience for visitors, available to all without discrimination by gender, race, and disability or in other ways.

$\checkmark \quad$ Local Control: To engage and empower local communities in planning and decision making about the management and future development of tourism in their area, in consultation with other stakeholders.

$\checkmark \quad$ Community Well being: To maintain and strengthen the quality of life in local communities, including social structures and access to resources, amenities and life support systems, avoiding any form of social degradation or exploitation.

$\checkmark \quad$ Cultural Richness: To respect and enhance the historic heritage, authentic culture, traditions and distinctiveness of host communities.

$\checkmark \quad$ Physical Integrity: To maintain and enhance the quality of landscapes, both urban and rural, and avoid the physical and visual degradation of the environment.

$\checkmark \quad$ Biological Diversity: To support the conservation of natural areas, habitats and wildlife, and minimize damage to them.

$\checkmark \quad$ Resource Efficiency: To minimize the use of scarce and non-renewable resources in the development and operation of tourism facilities and services.

$\checkmark \quad$ Environmental Purity: To minimize the pollution of air, water and land and the generation of waste by tourism enterprises and visitors.

\subsection{Indicators}

Indicators are a useful tool for the organization / destination in order to prove for their sustainability. The MESST identify 50 indicators which some of them are presented in Table 2. Those indicators are divided in three pillars. Pillar one include Level of Integration in the Local Economy, Pillar two include Promotion of Local Society \& Culture and Pillar three include Environmental Protection.

The organization shall establish, implement and maintain a procedure in order to prove their performances in the indicators that are chose. The organization shall choose at least two indicators from each pillar and the organization shall implement, maintain and continual improve from year to year its sustainability. For each indicator 3 different value ranges should be established. The first value range will correspond to an entry level of sustainability the second range to a mature and the third one in an exceptional level of sustainability. The overall level of sustainability certification will be the statistical average of the individual levels of each indicator. For any indicator the organization shall establish a target (like ISO 9001:2000). 


\subsection{Actions/measures towards sustainable tourism development}

Many tourist enterprises believe that sustainable tourism development is not possible in some Countries, mainly due to "insufficient state policy regarding tourism development" and the "incapacity of local and regional authorities to undertake tourism development actions". However, the majority believes that tourism businesses could function properly under the sustainability model and they have mentioned "environmental education programmes" and "establishment of co-operation and partnerships among local, regional and state stakeholders and authorities" as the most sustainable actions. All businesses, which do not believe in that, are due to "oversupply" and "low quality of tourism product". Similarly to the tourism enterprises, the local authorities also believe that

Table 2: $\quad$ Indicators of MESST.

\begin{tabular}{|c|c|c|}
\hline Indicator & $\begin{array}{l}\text { Purpose- what the } \\
\text { indicator shows }\end{array}$ & Collected by \\
\hline $\begin{array}{l}\text { Total visitor arrivals } \\
\text { or bed nights per } \\
\text { month }\end{array}$ & $\begin{array}{l}\text { Tourism volume and } \\
\text { seasonality }\end{array}$ & $\begin{array}{ll}\text { Records } & \text { from } \\
\text { accommodation } & \\
\text { establishments } & \\
\end{array}$ \\
\hline $\begin{array}{l}\text { Local spending (or } \\
\text { GDP) generated by } \\
\text { tourism }\end{array}$ & $\begin{array}{l}\text { Tourism value } \\
\begin{array}{l}\text { contribution } \\
\text { economy }\end{array}\end{array}$ & $\begin{array}{l}\text { Visitor survey showing } \\
\text { spend plus business } \\
\text { survey on occupancy } \\
\text { (or local TSA process) }\end{array}$ \\
\hline $\begin{array}{l}\% \text { tourism enterprises } \\
\text { accessible by public } \\
\text { transport }\end{array}$ & $\begin{array}{l}\text { Potential to accommodate } \\
\text { non-car access and need } \\
\text { for improvement }\end{array}$ & $\begin{array}{l}\text { Facility audit and } \\
\text { business survey }\end{array}$ \\
\hline $\begin{array}{l}\text { Total employment in } \\
\text { sector as percent of } \\
\text { total employment }\end{array}$ & $\begin{array}{l}\text { Relative importance of } \\
\text { tourism jobs and balance } \\
\text { in the economy }\end{array}$ & $\begin{array}{l}\text { Industry sector records/ } \\
\text { codes }\end{array}$ \\
\hline $\begin{array}{l}\% \text { of enterprises with } \\
\text { recognized } \\
\text { environmental } \\
\text { certification }\end{array}$ & $\begin{array}{l}\text { A robust indication that } \\
\text { action is actually being } \\
\text { taken }\end{array}$ & $\begin{array}{lr}\text { Records } & \text { from } \\
\text { certification } & \text { schemes } \\
\text { and/or business survey }\end{array}$ \\
\hline $\begin{array}{l}\text { Water consumption } \\
\text { (Total or sum from } \\
\text { tourism) }- \text { total and } \\
\text { at busier period }\end{array}$ & $\begin{array}{l}\text { Resource efficiency and } \\
\text { community impact }\end{array}$ & $\begin{array}{l}\text { Municipal measurement } \\
\text { or sum of data } \\
\text { submitted by tourism } \\
\text { enterprises }\end{array}$ \\
\hline $\begin{array}{l}\text { Number and size of } \\
\text { protected sites and } \\
\text { land area }\end{array}$ & \begin{tabular}{llr} 
Natural & and cultural \\
heritage & \multicolumn{2}{c}{ quality and } \\
ability & to withstand \\
pressure & &
\end{tabular} & Recorded designations \\
\hline $\begin{array}{l}\% \text { of businesses that } \\
\text { belong to local } \\
\text { tourism association }\end{array}$ & $\begin{array}{l}\text { Degree of engagement by } \\
\text { the private sector in } \\
\text { destination management }\end{array}$ & Membership record \\
\hline
\end{tabular}


sustainable tourism growth has a positive prospect in some countries, as the vast majority of them believe that their area, on a destination and on an operational level, is able to meet sustainable growth. Local authorities suggest that the most crucial activities for them to meet sustainable tourism growth are the "organization of environmental and energy-save programmes", "setting a marketing plan for tourism development", "developing infrastructure', and "local stakeholders dynamic participation in decision making process". In addition, they feel that local tourism enterprises can easily implement sustainable tourism development principles, mainly through "recycling measures", "collaborating with the local community" and with the "promotion of local culture'. It is important to note the emphasis given by them on collective co-operation and the creation of an integrated framework.

\section{Conclusions}

On concluding, most of the tourist enterprises and the local authorities believe that tourism business could gain economic benefits through sustainable tourism development and the role of all groups involved is crucial for the sustainable tourism development. Thus, sustainable tourism should: (1) Make optimal use of environmental resources that constitute a key element in tourism development, maintaining essential ecological processes and helping to conserve natural heritage and biodiversity, (2) Respect the socio-cultural authenticity of host communities, conserve their built and living cultural heritage and traditional values, and contribute to inter-cultural understanding and tolerance, (3) Ensure viable, long-term economic operations, providing socio-economic benefits to all stakeholders that are fairly distributed, including stable employment and incomeearning opportunities and social services to host communities, and contributing to poverty alleviation.

\section{References}

[1] Zorpas Antonis. Mediterranean Standard For Sustainable TourismMe.S.S.T. European Union, Programme Interreg IIIB, ARCHIMED 2007

[2] EU. Actions for More Sustainable European Tourism. Report of the Tourism Sustainability Group. February 2007.

[3] prEN 15565, European Standard. Tourism Services - Requirements for the provision of professional training and qualification programmes of tourist guides, DRAFT.

[4] Cyprus Tourism Organization. Mediterranean standard for sustainable tourism, situation analysis of the sustainable tourism development in Cyprus, sponsored by the European community initiative programme interreg iii b archimed. January 2007. 